\title{
Peran Mahkamah Pelayaran dalam Pemeriksaan Lanjutan (Persidangan) pada Nahkoda Kapal yang Mengalami Kecelakaan
}

\author{
Christmas $^{1}$, Misbahul Huda ${ }^{2}$, Gunawan Nachrawi ${ }^{3}$ \\ 1,2,3 Sekolah Tinggi Ilmu Hukum IBLAM, Jakarta Pusat, Indonesia \\ E-mail:christ@datumbanua.com,misbahulhuda90@gmail.com,gunawannachrawi@gmail.com
}

Published: 2022-03-04

Keywords:

Maritime Court;

Jurisdiction;

Maritime Judiciary.

\section{Article Info \\ Article History \\ Received: 2022-02-03 \\ Revised: 2022-02-22}

\begin{abstract}
Article 1 number (58) of Law no. 17 of 2008 concerning Shipping stated that the Maritime Court is a panel of experts who are under and responsible to the Minister who is in charge of conducting follow-up inspections of ship accidents. The inspection is carried out to find out the causes of ship accidents and/or determine whether or not there are errors or omissions in the application of marine professional standards carried out by the skipper or ship leadership and/or ship officers in connection with the ship accident. The formulation of the problem that the author discusses are: 1) What is the role of the Shipping Court in uncovering the occurrence of ship accidents? and 2) What is the responsibility of the Shipping Court in resolving cases of ship accidents? The research method that the author uses is the normative juridical method, which is to analyze the relationship between the applicable laws and regulations with legal theories and the practice of implementing positive law concerning the issues discussed. Based on the results of the study, the authors conclude that the responsibility of the Shipping Court in resolving cases of ship accidents, the Maritime Court is not currently a judicial body, and its position is not within the General Court.
\end{abstract}

\begin{tabular}{l}
\hline Artikel Info \\
\hline Sejarah Artikel \\
Diterima: 2022-02-03 \\
Direvisi: 2022-02-22 \\
Dipublikasi: 2022-03-04
\end{tabular}

Kata kunci:

Mahkamah Pelayaran; Yurisdiksi;

Lembaga Peradilan Maritime.

\begin{abstract}
Abstrak
Pasal 1 angka (58) UU No. 17 Tahun 2008 tentang Pelayaran mengemukakan bahwa Mahkamah Pelayaran adalah panel ahli yang berada dibawah dan bertanggung jawab kepada Menteri yang bertugas untuk melakukan pemeriksaan lanjutan kecelakaan kapal. Pemeriksaan dilakukan untuk mengetahui sebab-sebab terjadinya kecelakaan kapal dan/atau menentukan ada atau tidaknya kesalahan atau kelalaian dalam penerapan standar profesi kepelautan yang dilakukan oleh Nakhoda atau pimpinan kapal dan/atau Perwira Kapal dalam kaitan terjadinya kecelakaan kapal. Rumusan masalah yang penulis bahas adalah: 1) Bagaimana peran Mahkamah Pelayaran dalam mengungkap terjadinya kecelakaan kapal? dan 2) Bagaimana tanggungjawab Mahkamah Pelayaran dalam menyelesaikan kasus terjadinya kecelakaan kapal? Metode penelitian yang penulis gunakan adalah metode yuridis normatif, yaitu menganalisis kaitan antara peraturan perundang-undangan yang berlaku dengan teori-teori hukum dan praktek pelaksanaan hukum positif yang menyangkut permasalahan yang dibahas. Berdasarkan hasil penelitian, penulis menyimpulkan bahwa tanggungjawab Mahkamah Pelayaran dalam menyelesaikan kasus terjadinya kecelakaan kapal, Mahkamah Pelayaran saat ini bukanmerupakan badan peradilan, dan kedudukannya pun tidak dalam lingkungan Peradilan Umum.
\end{abstract}

\section{PENDAHULUAN}

Seperti kita ketahui Indonesia adalah suatu Negara kepulauan karena luas wilayah Indonesia dari dua pertiganya adalah terdiri dari lautan, dan mempunyai panjang pantai terbesar di dunia setelah Kanada, disamping itu letak wilayah yang sangat strategis karena lokasinya diantara dua benua dan dua samudera terkenal dengan sebutan "Indonesia Locked Country" oleh karena itu berpengaruh dan menunjang kelancaran pengiriman barang didalam dunia perdagangan Internasional (Prayoga,2018). Perkembangan suatu pelabuhan bisa dilihat dan ditentukan dari perkembangan aktivitas perdagangan disuatu daerah tersebut, semakin ramai aktivitas jual beli atau perdagangan di daerah itu maka pelabuhan tersebut akan semakin besar karena pergerakan barang lancar, di dalam Bisnis perdagangan juga menentukan jenis kapal serta lalu lintas kapal yang akan melewati pelabuhan tersebut. Sehingga beberapa negara berencana untuk membuat dan membangun Pelabuhan disesuaikan dengan tingkat kesibukan dan barang-barang yang dapat ditampung oleh pelabuhan tersebut, dengan demikian, kemajuan satu pelabuhan akan selalu bersama dengan kemajuan ekonomi negara (Sumardiman, 2009), sehingga sarana dan fasilitas perhubungan laut menjadi prioritas yang penting sebab untuk menghubungkan kota yang satu dengan 
kota lain apalagi antara pulau satu dengan pulau lainnya, dibutuhkan suatu sarana transportasi agar tujuan tersebut tercapai. Angkutan adalah angkutan barang dari suatu tempat diterimanya barang tersebut ke suatu tempat yang ditentukan untuk penyerahan barang yang bersangkutan (Sujono, 2002), dalam pelayaran kapal adalah Salah satu faktor penting. Sebab semua alat transportasi laut, baik untuk mengangkut barang maupun mengangkut penumpang sudah tentu memakai kapal sebagai alat transportasinya, disamping kapal mempunyai daya angkut yang lebih besar dibandingkan dengan perahu tradisional, kapal juga mempunyai perlengkapan dan alat-alat keselamatan yang jauh lebih baik dari pada perahu tradisional, menjadikan suatu pelayaran yang aman dan nyaman. Kapal adalah kendaraan air dengan bentuk dan jenis tertentu yang digerakkan dengan tenaga angin, tenaga mekanik dan energi lainnya, ditarik atau ditunda, termasuk kendaraarn yang berdaya dukung dinamis, kendaraan dibawah permukaan air serta alat apung dan bangunan terapung yang tidak berpindah, melihat kebutuhan yang semakin banyak akan sarana transportasi laut, sehingga sekarang banyak perusahaan milik negara ataupun milik swasta yang ingin mengambil bagian dalam penyelenggaraan angkutan laut, sedangkan yang dimaksud dengan alat perlengkapan kapal adalah segala benda yang bukan suatu bagian dari pada kapal itu sendiri, namun diperuntukkan untuk selamanya dipakai tetap dengan kapal itu (Sujono, 2002).

Didalam suatu operasional pelayaran kapal sangat mungkin terjadi suatu insiden atau kecelakaaan kapal dalam pelayaran, pengertian kecelakaan kapal dapat berupa kapal karam dan kapal terdampar tidak diberikan dalam KUHD, tetapi diatur dalam satu bagian (title VII), kapal karam, kapal pecah, dan kapal terdampar meskipun secara yuridis mempunyai akibat hukum yang sama, yaitu dalam pertolongan, penyelamatan dan penemuan barang-barang di laut. Dalam KUHD hanya dibedakan dalam hal tempat kejadian di tanah pantai atau di bagian luar (lepas pantai, di laut) (Chidir, 2001), jika terjadi suatu peristiwa karam, tubrukan, pecah, serta terdampar maka harus cepat diambil Tindakan untuk pertolongan terhadap penumpang dan penyelamatan barang-barang, pertolongan pada orang dan penyelamatan barang diatur dalam KUHD dan Konvensi Internasional di Bruseel pada tanggal 27 Mei 1967, yaitu International Convention for The Unification od Certain Rules of Law Relating to Asstance and
Salvage at Sea (Thamrin, 2015). Kecelakaan pada kapal meliputi pemeriksaan pendahuluan dan pemeriksaan Lanjutan, setiap kecelakaan pada kapal yang dilaporkan oleh Nahkoda kepada Syahbandar, akan dilakukan pemeriksaan pendahuluan oleh syahbandar dan hasil pemeriksaan akan di laporkan ke Menteri Perhubungan, jika Menteri perhubungan menilai ada kesalahan dan kelalain dalam menjalakan standar profesi kelautan maka Menteri perhubungan meminta Mahkamah Pelayaran Untuk pemeriksaan Lanjutan kecelakaan kapal.

Pasal 1 angka (58) UU No. 17 Tahun 2008 tentang Pelayaran mengemukakan bahwa Mahkamah Pelayaran adalah panel ahli yang berada dibawah dan bertanggung jawab kepada Menteri yang bertugas untuk melakukan pemeriksaan lanjutan kecelakaan kapal, pemeriksaan yang dilakukan oleh Mahkamah Pelayaran adalah untuk menyelidiki serta menentukan ada atau tidaknya kelalaian dalam menjalankan standar profesi kepelautan diatas kapal yang dilakukan pimpinan kapal (Nakhoda) atau Perwira Kapal dalam hal terjadinya kecelakaan. Hasil dari pemeriksaan itu bisa di jadikan sebagai pedoman atau pelajaran untuk mencegah terjadinya kecelakaan kapal dengan sebab-sebab kecelakaan yang sama (Utomo, 2015). Hasil dari pemeriksaan itu, bisa dijadikan sebagai suatu bentuk pembinaan dan pengawasan bagi tenaga profesi kepelautan, kalau melihat pada aturan-aturan yang melandasi Mahkamah Pelayaran, Mahkamah Pelayaran ini adalah bukan bagian dari badan peradilan (yudikatif), akan tetapi merupakan bagian dari badan eksekutif atau pemerintah yaitu Kementrian Perhubungan, hal ini secara tegas dinyatakan dalam Pasal 250 UU No. 17 Tahun 2008 Mahkamah Pelayaran dibentuk oleh dan bertanggungjawab kepada Menteri. Menteri di sini ialah Menteri yang tugas dan tanggung jawabnya di bidang pelayaran (Pasal 1 angka (58)(Utomo, 2015). Walaupun memakai predikat "Mahkamah" lebih umumnya dikenal dengan "peradilan", tetapi Mahkamah Pelayaran ini tidak mempunyai kewenangan yuridis untuk menangani perkara yang ada kaitan dengan kerugian yang dialami dan adanya unsur pidana, sebab Mahkamah Pelayaran ini hanyalah Lembaga eksekutif. Pemeriksaan dalam sidang Mahkamah Pelayaran biasanya dimanfaatkan oleh badan Hukum Perdata atau perorangan yang merasa kurang puas dengan keputusan Badan atau Pejabat Tata Usaha Negara (Agoes, 
2015), keadaan putusan ini atau kondisi dalam lingkup bidang pelayaran.

\section{METODE PENELITIAN}

Kajian ini menggunakan pendekatan kualitatif dengan metode deskriptif yaitu dengancara mengumpulkan, menganalisis, membuat gambaran dan mempersingkat segala kondisi dan situasi dari data yang telah terkumpul, penelitian ini merupakan penelitian kualitatif reflektif dengan pendekatan studi Pustaka. Data - data diambil dari berbagai sumber seperti buku, jurnal dan lainnya, analisis data yang dilakukan untuk menjawab permasalahan yang ada pada penelitian ini adalah reduksi data, yang selanjutnya dianalisis berdasarkan teori teori yang dipilih dalam penelitian ini dan disajikan dalam bentuk narasi ilmiah.

\section{HASIL DAN PEMBAHASAN}

\section{Kewenangan Yuridis Mahkamah Pelayaran}

Jika terjadi kecelakaan kapal, maka Syahbandar segera melakukan pemeriksaan terlebih dahulu dan pejabat pemerintah telah ditentukan oleh Menteri, berdasarkan pemeriksaan kecelakaan kapal yang di laporkan. Menurut Pasal 8 ayat (1) dan (2) Peraturan Pemerintah Republik Indonesia Nomor 1 Tahun 1998 Tentang Pemeriksaan Kecelakaan Kapal dijelaskan bahwa: "Pemeriksaan pendahuluan kecelakaan kapal dilaksanakan atas dasar laporan kecelakaan kapal" (PP No 1 Tahun 1998). Pemeriksaan pendahuluan kecelakaan kapal sebagaimana dimaksud dalam ayat (1) dilaksanakan oleh:

a) Syahbandar, setelah menerima laporan kecelakaan kapal dari pelapor.

b) Pejabat Pemerintah yang ditunjuk oleh Menteri, setelah Menteri menerima laporan kecelakaan kapal dari Pimpinan Perwakilan Republik Indonesia dan/atau dari pejabat Pemerintah negara setempat yang berwenang."

Menteri akan menerima laporan setelah laporan kecelakaan selesai, tugas Menteri adalah menetapkan ada atau tidaknya praduga kecerobohan yang telah terjadi di kapal oleh nakhoda atau perwira. Selanjutnya laporan diserahkan kepada Mahkamah Pelayaran untuk diputuskan, sebagaimana Pasal 15 Peraturan Pemerintah Republik Indonesia Nomor 1 Tahun 1998 Tentang Pemeriksaan Kecelakaan Kapal menyatakan, "Apabila berdasarkan hasil pemeriksaan pendahuluan kecelakaan kapal. Menteri berpendapat adanya dugaan kesalahan dan/atau kelalaian dalam menerapkan standar profesi kepelautan yang dilakukan oleh Nakhoda atau pemimpin kapal dan/atau perwira kapal atas terjadinya kecelakaan kapal, maka selambatlambatnya dalam jang-ka waktu 14 (empat belas) hari sejak diterimanya hasil pemeriksaan pendahuluan kecelakaan kapal, Menteri meminta Mah-kamah Pelayaran melakukan pemeriksaan lanjutan kecelakaan kapal. (PP No 1 Tahun 1998). Hasil putusan Mahkamah Pelayaran dari proses persidangan terdiri dari beberapa aspek teknis kapal, antara lain yaitu:

a) Kapal, surat kapal dan pengawakan kapal;

b) Keadaan cuaca;

c) Muatan kapal atau Penumpang;

d) Sarat dan stabilitas kapal;

e) Olah gerak dan Navigasi;

f) Sebab kecelakaan kapal;

g) Upaya penyelamatan;

h) Kelalaian atau Kesalahan (PP No 1 Tahun 1998).

Tetapi jika peristiwa kecelakaan kapal yang telah diketahui, selain aspek teknis dan nautis juga adanya aspek lain yang sama pentingnya, yaitu aspek perdata atau pidana, dari aspek-aspek tersebut jika melihat aturan tentang yurisdiksi Mahkamah Pelayaran, maka Mahkamah ini bukan menjadi tanggung jawab dalam bidang tersebut, akan tetapi adalah yurisdiksi lembaga peradilan umum, contohnya ketika suatu kejadian kecelakaan kapal murni terjadi karena kesalahan nakhoda dan kapal tersebut terdapat bermuatan barang impor, maka disini ada pihak yang telah dirugikan. Contoh lainnya, jika kecelakaan kapal yang terbukti ada unsur kesengajaan dari Nakhoda/pemimpin kapal sehingga mengakibatkan korban jiwa, maka kasus ber perkara diserahkan kepada pihak yg berwajib (kepolisian), untuk menyidik dan meyelidik perkara juga memeriksa Nakhoda kapal atas dasar prasangka melakukan tindak pidana. Disisi lain adapun tentang kerugian yang diakibatkan, maka keputusan untuk ganti rugi bagi pihak yang dirugikan akan diputuskan di pengadilan (Handayani, 2015).

Dalam hal ini Mahkamah Pelayaran tidak mempunyai peranan, dan faktanya pihak yang dirugikan (pemilik kapal, pemilik muatan kapal, operator kapal dan penumpang kapal ) adanya kejadian kecelakaan kapal, tentunya keputusan yang sifatnya administratif seperti menjatuhkan skorsing terhadap Nakhoda atau pemimpin kapal yang mereka nilai penting 
yaitu bagaimana ganti rugi dan kompensasi di dapat dari kerugian yang terjadi .

Para nelayan usaha perhotelan serta pengusaha wisata bahari akan mengalami kerugian dan segala aktifitas mereka akan terhenti dikarenakan lingkungan perairan tempat mereka melakukan kegiatan sudah mengalami pencemaran. Persoalan tentang teknis nautis tidak akan mempengaruhi pola pikir mereka, hal terpenting bagi mereka iyalah bagaimana mendapatkan ganti rugi dan kompensasi yang pantas dan sesuai dengan kerugian ekonomi yang mereka alami.

Dalam pelaksanaan pemeriksaan lanjutan, tugas Mahkamah Pelayaran sebatas melakukan penelitian penyebab terjadinya kecelakaan kapal serta memutuskan ada atau tidaknya kesalahan yang dilakukan oleh Nakhoda atau Perwira kapal agar dapat dijatuhi sanksi administratif, dalam Pasal 18 Peraturan Pemerintah Republik Indonesia Nomor 1 Tahun 1998 mengenai Pemeriksaan Kecelakaan Kapal disebutkan, dalam pemeriksaan lanjutan kecelakaan kapal, Mahkamah pelayaran bertugas melaksanakan:

a) Meneliti sebab-sebab kecelakaan kapal dan menentukan ada atau tidak adanya kesalahan atau kelalaian disaat penerapan standar profesi kepelautan oleh Nakhoda atau pemim-pin kapal dan/atau perwira kapal atas ter-jadinya kecelakaan kapal.

b) Menjatuhkan sanksi administratif kepada Nakhoda atau pemimpin kapal dan/atau perwira kapal bersertifikat keahlian Pelaut yang dikeluarkan pemerintah Indonesia dalam pekerjaannya melakukan kesalahan atau kelalaian (PP No 1 Tahun 1998).

Hasil dari pada pemeriksaan pendahuluan dilaporkan berbentuk berita acara pemeriksaan pendahuluan kecelakaan kapal dan ditanda-tangani oleh tim pemeriksa dan pihak yang diperiksa. Selanjutnya syahbandar atau pejabat pemerintah yang ditunjuk oleh Menteri Perhubungan melaksanakan verifykasi dalam waktu paling lambat 3 hari kerja terhitung sejak terbitnya berita acara pemeriksaan selesai. Kemudian memverifikasi berita acara pemeriksa-an pendahuluan, dilanjutkan dengan melakukan pelaporan hasil dari pemeriksaan kepada Menteri Perhubungan dan pihak lainnya dalam waktu paling lambat 7 hari kerja terhitung sejak berita acara diverifikasi, adapun lainnya yaitu:
a) Mahkamah Pelayaran, apabila telah diketahui keterangan serta bukti awal terkait adanya dugaan kelalaian maupun kesalahan yang dilakuakan oleh nakhoda dan/atau perwira kapal dalam menerapkan standar profesi kepelautan yang dilakukan atas kecelakaan kapal yang terjadi.

b) Penyidik pegawai negeri sipil, apabila diketahui keterangan serta bukti awal terkait adanya dugaan tindak pidana pelayaran sebagai faktor penyebab terjadinya kecelakaan kapal.

c) Penyidik Polisi Negara Republik Indonesia, apabila diketahui keterangan atau bukti awal mengenai dugaan tindak pidana umum menjadi faktor penyebab kecelakaan kapal terjadi (Malisan, 2012).

Akibat dari Tindakan dan kelanjutan proses pemeriksaan pendahuluan maka berhak di-laksanakan pemeriksaan lanjutan yaitu Mahkamah Pelayaran dengan sifat terbuka bagi umum. Dilaksanakan dalam kurun waktu paling lambat 7 hari kerja terhitung dari dokumen-dokumen diterima terkait laporan secara lengkap, selanjutnya tim panel ahli yang keanggotaannya paling sedikit 5 (lima) orang akan dibentuk Mahkamah pelayaran dan harus berjumlah ganjil. Selanjutnya dalam waktu paling lambat 20 hari kerja terhitung sejak ter-bentuknya tim panel ahli oleh ketua Mahkamah Pelayaran, tim panel ahli sesegera mungkin wajib mengadakan sidang pertama di tempat kedudukan Mahkamah Pelayaran atau di luar tempat kedudukan Mahkamah Pelayaran. Halhal yang perlu diperhatikan dalam persidangan pertama yang digelar oleh tim panel ahli yaitu melaksanakan pemeriksaan yang didasari oleh data serta fakta akurat dalam dokumen pemeriksaan pendahuluan, alat bukti dan surat dokumen lainnya yang dapat dipertanggung jawabkan kebenaran dan keasliannya secara hukum. Adapun alat bukti tersebut terdiri dari:

a) Berkas dokumen surat atau tulisan;

b) Keterangan terduga;

c) Keterangan para saksi;

d) Keterangan para ahli;

e) Keterangan para pihak yang terkait;

f) Petunjuk atau gambaran; dan/atau

g) Informasi yang disampaikan, dikirim dan diterima, atau disimpan dengan alat perang-kat optik atau yang serupa dengan itu (Malisan, 2012). 


\section{Tanggungjawab Mahkamah Pelayaran}

Beberapa hal yang harus diperhatikan apabila terjadi kecelakaan kapal yaitu sebagai berikut:

a) Cepat tanggap dan teliti dalam menghadapi kecelakaan kapal tersebut.

b) Jangan lupa untuk selalu mengumpulkan berbagai bukti-bukti otentik.

c) Nahkhoda, Perwira dan awak kapal harus selalu mempertahankan keberadaan kapal dan tidak memperburuk keadaan maupun situasinya. Serta diharapkan untuk sesegera mungkin harus melaporkan musibah/kecelakaan kapal yang terjadi kepada pemilik kapal atau pihak yang terkait, tindakan ini jangan dianggap remeh, tetapi harus segera melaporkan. Pengumpulan bukti dan data Nakhoda sebuah kapal harus wajib dan telah siap membuat dan mengumpulkannya (Barus, 2017).

Pada umumnya log book atau beberapa buku harian terdapat pada setiap kapal seperti, buku harian mesin, buku harian radio, buku harian harian geladak, buku harian jaga di anjungan, dan yang paling utama yaitu buku harian kapal, yang tidak terdapat coretan serta tidak halaman yang hilang, apabila terjadi kesalahan pada saat penulisan harus segera dibubuhi paraf dimana kesalahan tersebut ditulis. Sehingga bilamana kecelakaan kapal terjadi atau musibah maka hal yang paling pertama di minta yaitu menunjukan buku harian kapal agar dapat dipelajari seperti KNKT oleh petugas yang berkewenang dan Nakhoda kapal dapat meyakinkan serta harus dapat menjawab dengan benar sesuai kejadian yang terjadi, dan para perwira atau ABK ( Barus, 2017). Nakhoda harus tidak ada perubahan posisi kapal dari posisi yang ada atau posisi sebelumnya tidak dihapus, karena pada alur pelayaran sempit banyak terjadi pelanggaran kapal dan dengan perantara seorang pandu, Nakhoda harus jeli mengamati posisi kapal dan rambu-rambu atau semua posisi yang telah dicatat di peta dan jarak terhadap rambu-rambu. Nakhoda harus memperhatikan dengan seksama semua yang telah dicatat pada buku olah gerak ditulis dengan tinta yang dapat terbaca dengan jelas dan tidak ada yang di hapus atau tercoret dan ditandatangani yang bertanggung jawab . Untuk kapal-kapal yang memiliki mesin printer dan bisa melakukan printout dan setiap kegiatan akan direkam secara rinci tercatat pada mesin saat waktu jam maju ataupun waktu jam mundur (Barus, 2017 ).

Hal yang berhubungan dengan persoalan peningkatan mutu kompetensi dan yurisdiksi Mahkamah Pelayaran sebagai sebuah lembaga "peradilan pelayaran" yang independen, terbagi menjadi empat yaitu:

a) Sejauh mana penetapan peraturan terkait tugas atau fungsi Mahkamah Pelayaran dapat memfasilitasi lembaga ini untuk menjalankan tugas dan fungsinya sebagai sebuah "Peradilan" atau lembaga yang bertugas menyelesaikan segala aspek yang terkait dengan perkara kecelakaan kapal.

b) Sejauh mana perangkat terhadap unsur sumberdaya manusia dan kelembagaan telah menyokong ke arah yang membentuk lembaga "peradilan" maritim atau pelayaran.

c) Halangan apa saja yang bisa menghambat proses pelaksanaan tugas dan fungsi Mahkamah Pelayaran dalam melaksanakan tugasnya.

d) Bagaimana perkembangan urgensi peningkatan yurisdiksi serta kompetensi Mahkamah Pelayaran agar menjadi lembaga peradilan berdiri sendiri (Rahman, 2018).

Walau pun telah diatur pada sejumlah peraturan perundang-undangan, akan tetapi hal yang sebenarnya kita hadapi pada yurisdiksi serta kompetensi Mahkamah Pelayaran di Indonesia masih sangat terbatas, Mahkamah Pelayaran yang sudah ada saat ini hanya sebatas memberikan penindakan disiplin, atau dalam bahasa UU No. 22 tahun 1999 "bertugas terbatas pada menjatuhkan sanksi berupa hukuman administratif yang berkaitan dengan profesi kepelautan". Mahkamah Pelayaran memiliki kewenangan melaksanakan pemeriksaan lanjutan guna pengambilan keputusan pada kecelakaan kapal, antara lain memberikan sanksi berupa hukuman/tindakan administratif yang berhubungan dengan profesi kepelautan, di dalam kasus-kasus atau kejadian:

a) Kapal tenggelam.

b) Kapal terbakar.

c) Kapal tubrukan yang mengakibatkan kerusakan berat.

d) Kecelakaan kapal yang menyebabkan kerugian harta benda dan terancamnya jiwa manusia. 
e) Rusak berat dan kapal kandas (Academia, edu, 2021).

\section{SIMPULAN DAN SARAN}

\section{A. Simpulan}

Peran Mahkamah Pelayaran dalam mengungkap terjadinya kecelakaan kapal dan mencari ada atau tidaknya kelalain/keslahan nakhoda atau perwira kapal dalam menjalankan tugasnya sehingga Mahkamah Pelayaran bisa menjatuhkan sanksi administratif, berdasarkan ketentuan Pasal 18 Peraturan Pemerintah Republik Indonesia Nomor 1 Tahun 1998 Tentang Pemeriksaan Kecelakaan Kapal dinyatakan, dalam melaksanakan pemeriksaan lanjutan kecelakaan kapal, Mahkamah Pelayaran bertugas: (1) meneliti sebab-sebab kecelakaan kapal dan menentukan ada atau tidak adanya kesalahan atau kelalaian dalam penera-pan standar profesi kepelautan oleh Nakhoda atau pemimpin kapal dan/atau perwira kapal atas terjadinya kecelakaan kapal, (2) Menjatuhkan sanksi administratif kepada Nakhoda atau pemimpin kapal dan/atau perwira kapal yang memiliki sertifikat keahlian Pelaut yang dikeluarkan oleh pemerintah Indonesia yang melakukan ke salahan atau kelalaian dalam menerap-kan standar profesi kepelautan.

Tanggungjawab Mahkamah Pelayaran dalam menyelesaikan kasus terjadinya kecelakaan kapal, Saat ini Mahkahma pelayaran bukan merupakan badan peradilan dan kedudukannya pun tidak dalam lingkungan peradilan umum, dengan demikian sesungguhnya Mahkamah Pelayaran tidak memiliki yurisdiksi untuk memutuskan perkara yang berkaitan dengan aspek keperdataan (seperti tanggung jawab pengangkut, ganti rugi dan kompensasi ekonomi) atau aspek pidana, sekalipun timbul dalam kaitan dengan kecelakaan kapal, karena masalah-masalah ini merupakan yurisdiksi peradilan umum, oleh sebab itu yuridiksi dan kopentensi Mahkamah Pelayaran belum dapat disetarakan dengan Lembaga peradilan Maritim. Kasus-kasus yang masuk di mahkamah pelayaran yang dilimpahkan dari Syahbandar tidak terlalu berjalan secara maksimal, karena kasus-kasus yang ditangani oleh Mahkamah Pelayaran datang dari berbagai penjuru tanah air, sehingga instasi instasi yang terlibat dalam kasus kecelakaan kapal pada umumnya belum maksimal berjalan secara sinergis, sehingga untuk meningkatkan Kompetensi dan Peran Mahkamah Peayaran dalam Menyelasaikan perkara-perkara kecelakaan yang kapal yang sedang ditangani dan diperlukan perbaikan sehinga perkara-perkara bisa berjalan dengan cepat dan efesien, sehingga ada kepastian hukum untuk para Nakhoda Kapal dan Perwira yang mengalami Kecelakaan Kapal. Oleh karena saat ini lokasi kantor Mahkamah Pelayaran berada di Jakarta tidak ada perwakilan di daerah, sehingga akan menimbulkan permasalahan-permasalahan dalam proses persidangan, sedangkan perkara-perkara kecelakaan kapal harus ditangani tersebar di seluruh wilayah Indonesia, sehingga diperlukan perwakilan-perwakilan Mahkamah Pelayaran di wilayah-wilayah tertentu untuk memberikan percepatan penyelesaian perkara-perkara pada kecelakaan kapal.

\section{B. Saran}

Pembahasan terkait penelitian ini masih sangat terbatas dan membutuhkan banyak masukan, saran untuk penulis selanjutnya adalah mengkaji lebih dalam dan secara komprehensif tentang Peran Mahkamah Pelayaran dalam Pemeriksaan Lanjutan (Persidangan) pada Nahkoda Kapal yang Mengalami Kecelakaan.

\section{DAFTAR RUJUKAN}

Aditya Prayoga, "Perlindungan Hukum Atas Keselamatan Penumpang KM.Kirana IX Dalam Hal Terjadi Kecelakaan Kapal", Jurnal MahasiswaUnesa, Vol. 2, No. 01, 2018.

Agoes, Etty R. Laporan Akhir Tim An alisis Evaluasi Peraturan Perundang-Undangan tentang Yurisdiksi dan Kompetensi Mahkamah Pelayaran. (Jakarta: Laporan Akhir dari Badan Hukum dan HAM, 2015).

Ali, Chidir. Yurisprudensi Mahkamah Pelayaran Indonesia Tahun 1992-2002. (Bandung: Binacipta, 2001).

Dellyana, Shant. Konsep Penegakan Hukum. (Yogyakarta, Liberty, 2008)

Gayo, H. M. Iwan. Ed. Buku Pintar (Seri Senior). (Jakarta: Upaya Warga Negara, cet. 28, 2000)

Habibi 'Kegagalan Sistem Keselamatan Transportasi Laut di Indonesia (Failure of theMarine Transportation Safety System in 
Indonesia)', Jurnal Aplikasi Pelayaran dan Kepelabuhanan, 8(2), 2018, pp. 95-106

Hari Utomo,"Siapa Yang Bertanggung Jawab Menurut Hukum Dalam Kecelakaan Kapal", Jurnal Legislasi Indonesia, Vol. 14, No. 01, Maret,2017

HM. Thamrin. AR, "Manajemen Keselamatan Maritim Dan Upaya Pencegahan Kecelakaan Kapal Ke Titik Nol (Zero Accident)", Jurnal Ilmiah Widya, Vol. 3, No. 2, September Desember, 2015

Kamil, Faizal. Asas Hukum Acara Perdata dalam Teori dan Praktik. cet. 1 (Jakarta: Badan Penerbit IBLAM, 2005).

Keputusan Menteri Perhubungan Republik Indonesia Tentang Organisasi dan Tata Kerja Mahkamah Pelayaran". Kepmen Perhubungan No. 15 Tahun 1999

Lopa, Baharudin. Hukum Laut, Pelayaran dan Perniagaan. (Bandung: Alumni,2004)

Mahmud Marzuki, Penelitian Hukum, (Jakarta, Kencana, 2010)

Malisan J, Kajian Strategi Peningkatan Keselamatan Pelayaran Kapal-kapal Tradisional, Jurnal Litbang Perhubungan Volume 24 Nomor 3 Maret 2012, 218-231

Mulyadi, Lilik. Hukum Acara Pidana : Normatif, Teoritis, Praktik dan Permasalahannya. (Bandung : Alumni, 2007).

Pristika Handayani, "Kewenangan Syahbandar Selaku Komite Keamanan Pelabuhan (Port Security Committee) Berdasarkan UndangUndang Nomor 17 Tahun 2008 Tentang Pelayaran", Jurnal Petita, Vol. 2, No. 2, Desember, 2015.

Prodjodikoro, Wirjono. Hukum Laut Bagi Indonesia". Cet. 6. (Jakarta : Sumur Bandung, 2006).
Rahman, H. et al. 'Penentuan Faktor Dominan Penyebab Kecelakaan Kapal Di Kesyahbandaran Utama Tanjung Priok', ALBACORE Jurnal Penelitian Perikanan Laut, 1(3), 2018, pp. 277-284.

Ronny Hanitijo, Metodologi Penelitian Hukum, (Jakarta : Ghalia Indonesia, 2010)

Satjipto Rahardjo, Masalah Penegakan Hukum (Suatu Tinjauan Sosiologis), (Bandung, SinarBaru, 2010)

Soedjono, Wiwoho. Hukum Perkapalan dan Pengangkutan Laut. (Jakarta : Bina Aksara, 2002).

Soerjono, Soekanto, Pengantar Penelitian Hukum, (Jakarta, UI Press, 2010)

Sumardiman, Adi. Analisis dan Evaluasi Hukum Tentang Pengaturan Skema Pemisah Lalu Lintas Pelayaran. (Jakarta : Badan Pembinaan Hukum Nasional Departemen Kehakiman dan Hak Asasi Manusia RepublikIndonesia, 2009)

Undang-Undang Dasar Negara Rrepublik Indonesia Tahun 1945, Perubahan Keempat. Kitab Undang-undang Hukum Dagang Republik Indonesia ( Wetboek van KoOphandel). Diterjemahkan oleh R. Subekti dan R. Tjitrosoedibio, cet. 27,Jakarta: Pradnya Paramita, 2002.

Undang-undang Republik Indonesia Nomor 17 Tahun 2008 Tentang Pelayaran Peraturan Pemerintah Republik Indonesia Nomor 1 Tahun 1998 Tentang Pemeriksaan Kecelakaan Kapal.

Viana I.R. Barus, "Tugas dan Tanggung Jawab Syahbandar Dalam Kegiatan Pengangkut Laut di Indonesia", Diponegoro Law Journal, Vol. 6, No. 1, 2017 